\title{
A Gricean Maxim Analysis in Teaching and Learning Process at Higher Level Education
}

\author{
Sepri Kurniadi ${ }^{\mathrm{a}, 1, *}$ \\ ${ }^{a}$ Politeknik Aceh Selatan, Tapak Tuan, 23176, Aceh, Indonesia ${ }^{1}$ \\ * corresponding author:seprikurniadi@gmail.com
}

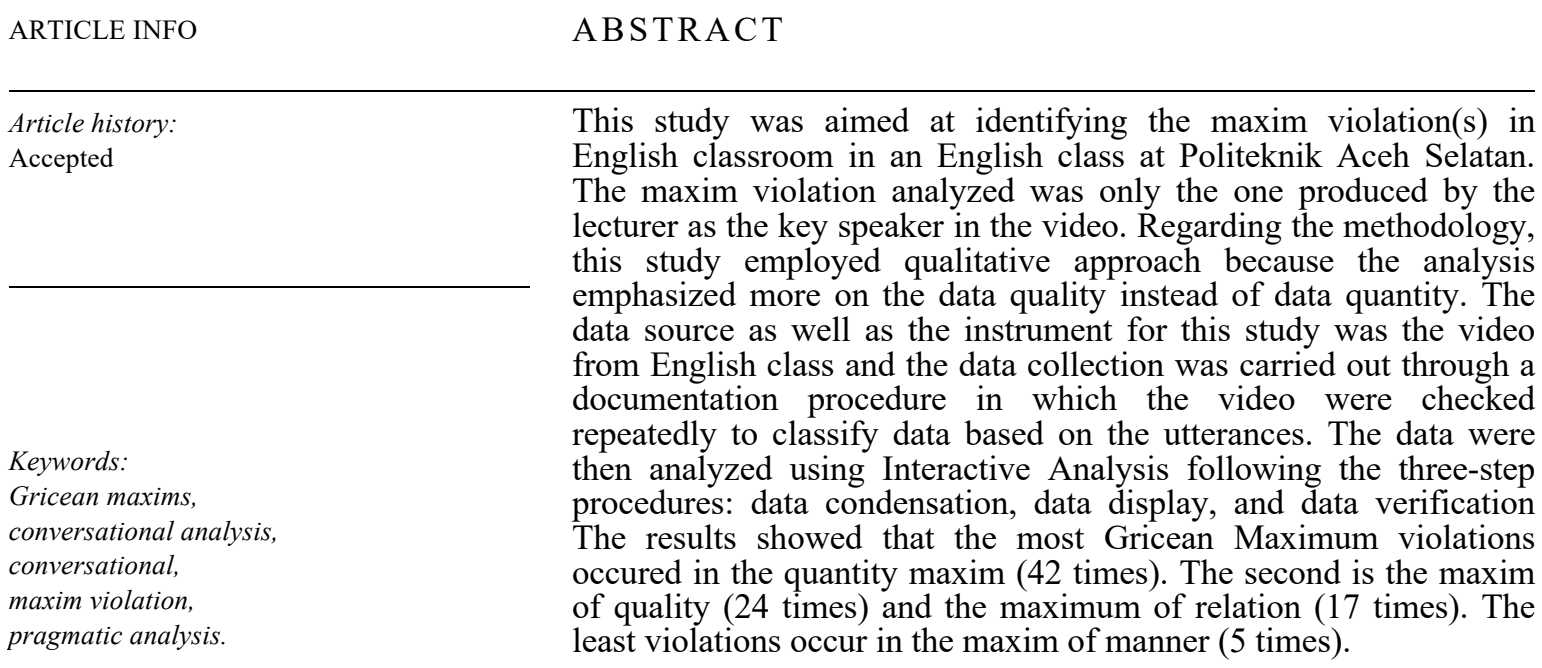

\section{Introduction}

The concept of pragmatics is an important concept in human communication. In pragmatics study, the meanings and intentions of utterances are specifically investigated in speech acts area [7]. Speech acts is one of pragmatics' basic ingredients arranging by words and corresponding to sentences and some ways to avoid kinds of misunderstanding in communication. This process needs to be understood by both speakers and hearers in order to get the expected output of the communication. If there is a misunderstading or misinterpretation taking place within the process, the aim of communication can distort or even fails [6]. The speaker needs to deliver the messages to his/her hearers, while the hearers need to catch the message without any misconceptions [13].

In pragmatics study, the meanings and intentions of utterances are specifically investigated in speech acts area. Speech Acts is one of pragmatics' basic ingredients arranging by words and corresponding to sentences and some ways to avoid kinds of misunderstanding in communication [8]. Various utterances have various purposes and meaning depending on the context. It is about what is going behind the utterances. These utterances must be understood by hearers depend on its context in order to make the speaker successful in conveying their messages.

Basically, the main problem that can be identified in a communication is from the continuing patterns of the interactions [16]. Specifically, concerning to speech acts in daily converstion, the problem appears from the regular patterns within the interactions between the speaker and the hearer. Daily conversation can clearly be seen in movies. It means that the patterns which are presented in movies are the ones that generally happen in daily life of human interaction.

Communication problems usually happen in human interaction because the hearer does not get the clear point that the speaker tries to say. However, the speker is also responsible for saying his/her ideas in an articulated way so that it can be easy for the hearers to convey. For some hearers, usually younger hearers, they only need to listen and execute the commands and requests. Meanwhile we 
know that in communication, both the speaker and the hearer need to give reactions toward the teacherseach others' intstruction to confirm and validize their comprehension or confusion. Furthermore, analyzing the speech act elements can reduce misinterpretation and misunderstanding in communication [18].

In analyzing speech acts, there are numerous theories proposed by experts in the pragmatics area [5]. After reviewing some of those theories, the reasearcher has decided to use the one proposed by Searle in 1980 because his speech act princinples are widely used and more precise as well as covers a wide breadth of concepts [14].

When making conversation with other people, we need to assemble a decent discussion. We also need to build the connection between the speaker and audience so that the participation of making great discussion between the speaker and audience is notable [17]. It portrays how individuals interface with one another. This standard ought to be done to make a discussion among them run well. In any case, language is futile without importance. Language really has to express and verify logical implications. According to such verifiable importance, there are four maxims in conversation as stated by Grice [10]; they are maxim of quality, maxim of quantity, maxim of relevance, and maxim of manner. These maxims need to be obtained to achieve satisfying discussions or conversations. When speakers do not deliberately satisfy these maxims, there will be maxim violation [10].

Grice formed rules for the productive and powerful utilization of language in conversations. The rules are known as the maxims of conversation. It ought to be underlined that Grice presents quantity, quality, relation and manner as classifications. The way that Grice communicated the agreeable guideline in the basic state of mind has driven some casual readers of his work to accept that Grice was advising speakers about how they should act. The fact is that he was recommending that in conversational discussions, individuals should work with the understanding that a specific arrangement of rules is in the procedural operation. This can be said so because in all circles of life we make comparable suspicions constantly.

During interactions with other people, we function as per a series of our own expectations and as what we get to understand. There will be times when we might suspend our supposition that our interlocutor is working as indicated by similar conversational standards as we are. We might be conversing with a small kid who still cannot seem to get our conversational standards, or to an alcoholic, or to somebody in pain, etc. Or then again we might be conversing with an individual whom we think might have distinctive conversational standards from our own. Furthermore, we also sometimes encounter the situation when our suspicions are not right and afterward errors and misconception happen, or when we are purposefully deluded by our interlocutor [11]

Table 1. Conversational maxim [10]

\begin{tabular}{|c|c|c|}
\hline Category & Supermaxim & Maxims \\
\hline Quantity & Frequency of the utterances & $\begin{array}{l}\text { Make contribution as } \\
\text { informative as required. }\end{array}$ \\
\hline & & $\begin{array}{l}\text { Do not make you } \\
\text { contribution } \\
\text { informative than is required. } \\
\text { more }\end{array}$ \\
\hline Quality & $\begin{array}{c}\text { Try to make your contribution } \\
\text { true }\end{array}$ & $\begin{array}{c}\text { Do not say what you believe } \\
\text { is false. } \\
\text { Do not say information } \\
\text { which you lack adequate } \\
\text { evidence. }\end{array}$ \\
\hline Relation & Be relevant & - \\
\hline Manner & Be perspicuous & $\begin{array}{l}\text { Avoid obscurity expression. } \\
\text { Avoid ambiguity. } \\
\text { Be brief and ordely. }\end{array}$ \\
\hline
\end{tabular}


The table above shows the Gricean conversational maxims: quantity, quality, relation, and manner. First, it is the maxim of quantity. Providing too much information during course of a conversation can be perceived as superfluous and insignificant to the other person. According to the second maxim, which requires one to be precise, the speaker should avoid unnecesssary, redundant information in his contribution. Then again, giving an excessive data during the course of a discussion can be seen as pointless and unimportant to the listener as the point of this maxim is to expect the speaker to be clear and brief. The speaker should not say unnecesssary and redundant data in his utterances.

Second, it is the maxim of quality. The maxim of honesty/truthfulness goes under the classification of quality. This maxim alludes to the significance of offering just expressions one accepts to be valid as Grice anticipates that that the contributions should be genuine and true. Hence, the speaker is required to be genuine and sincere. They are expected to remain silent if they accept something is not true or lacking evidence. The rationale if she/he offers untrue expressions is that she/he will lose an important social resource as an individual can have: believability.

Third, it is the maxim of relation. The maxim of relation is categorized under the classification of relation. In this maxim, the speaker is expected to be relevant during a conversation and the information given is necessary to be applicable to the context being discussed.

Last, it is the maxim of manner. Under the classification of manner, an utterance is seen from how it is being said rather than what is being said. It demands the speaker ought to be brief and deliberate, and stay away from haziness and vagueness opinions of information.

Grice urges that these maxims are vital to be followed during conversations as there maybe implicit suspicions we have in discussion. Individuals are typically going to give an appropriate measure of data [19]; which means that we accept that they are not telling lies, being relevant, and attempting to be as clear as possible. Since these standards are accepted in typical communication, speakers seldom notice them.

Exchanges in conversation whether in meetings, discussions, or other administration experiences will in general run as expected and effectively when the members follow certain social concensus as called conversational maxim [15]. Thomas [20] gave a fascinating situation when a speaker notices every one of the maxim as shown in the example below:

\section{Husband: Where are the car keys?}

\section{Wife: They are on the table in the hall.}

The wife does not violate any maxims as she answered in in a clear way and she meets the standard of manner. She gives true answer where she satisfies the maxim of quality. She gives right information - without lacking or being excessive - where she meets the maxim of quantity. And she meets her husband question which comes to click with the maxim of relation. She said the asnwer in a precise way, not more or less, and she does not build any further implicature. There is no additional meaning.

Several research has been previously conducted on this topic. Two of them are presented in this section. First, it is a study by Purwaningsih in 2015 [12]. She conducted a pragmatics research by applying Cooperative Principle in A Comedy Movie Entitled "Meet the Parents. She carried out this study by means of qualitative research following the procedures of observation, analyzing data along with example, and draw conclusion. The result shows that there are 62 conversations in line maxim and 39 conversations violated maxim. The majority maxim used in this movie is maxim of quality. Besides, she also found that this movie is induced with the American culture. The moral value that can be taken from this movie is honesty. All intention should be carried out with sincere honesty.

Second, it is a study by Zulfa in 2013 [19]. This study aimed at finding out the the conversational maxims in a movie entitled Dictator. This study was also conducted in the qualitative approach. The results reveal that the main characters made flouts in maxim of quantity, maxim of quality, maxim of relation and maxim of manner. For example, the main character become more informative, or even making jokes as the conversation occured.

During teaching and learning process, there could be a lot of maxim flouts and violation made by teachers that could lead students to misconception or confusion. The author was determined to 
analyze maxim violations produces during the interview three meetings in a college class, regardless of the motivation behind the productions. Briefly, this study aims at analyzing the maxim violations found during the teaching and learning process for three meetings. Hence, a research question formulated to frame this study is: "What are types of Gricean maxims violations produced in English class for higher education students?"

\section{Method}

This research deploys a qualitative design as Moleong states that qualitative methods are used in research procedures to explain information about a certain individual, behavior, or documents being considered [9]. In this case, a digital document was used as it refers to a teaching and learning video. Additionally, qualitative design is a research design strategy that does not involve mathematical measurements [2]. The mere purpose is to understand a phenomenon/an object a document explicitly [9].

The data sources used in this study are three teaching videos. In this study, the reseracher used primary data source because she collected the data on her own effort. Meanwhile the kinds of data in this study is qualitative data in the form of spoken discourse. As supported by Ajayi [1] that there are two sources of information: essential and optional information. Essential information (primary data) are simply the information gathered by the researcher, while optional information (secondary data) is the information that have been gathered by prior researchers.

Regarding to location of research, this study was conducted using a video so that there was no specific research location necessary to carry out this research. More specifically, The subject is three videos from the teaching and learning process that have ben transcribe. The object of this study is all the utterances containing violations of Gricean maxims produced by the lecturer only. In doing the analysis, the researcher used documentation as the research instruments. Documentation in language research is very crucial to comprehend the language use in a setting [3]-in this case, in the maxim violation in a podcast video. There are three types of documentation technique in qualitative research [4]. First, it is Observed Communicative Events whichis applied in conversations and stories.Second, it is Staged Communicative Events which can be foundin pictures and videos as this study utilized. An third, it is Elicitation. This last type is commonly employed in paradigms and judgments. Hence, in this study, the researcher used a video which is classified into the type 1 of documentation.

The data collection technique was carried out following the documentation steps [21]. The first step is to record the video. Then, the researcher watched the video carefully several times and transcribed them. Next, the researcher chose the data conceived in the video that were relevant to the purpose of this study. Then after identifying the data related to the research objectives, the researcher selects several examples from each category to be presented in the data display. Then the researcher classified and extracted data regarding the maxim of quantity, maxim of quality, maxim of relation, and maxim of manner from the video as a result of this research.

Later on, the data were analyzed using Interactive Analysis as suggested by Miles, Huberman, and Saldana [22]. There are three steps in this model, which are as follows. First, data condensation refers to the process of selecting, focusing, simplifying, abstracting, and transforming data into more relevant data in accordance to the research objective Second, the data are displayed in the form of graph showing the comparison of maxim violation. Finally, the data are verified based on each category, whether they are maxim of quantity, maxim of quality, maxim of relation, and maxim of manner to be taken conclusion from.

\section{Results and Discussion}

The results are as seen in the following Table 2 . 
Table 2. The result of maxim violation

\begin{tabular}{cccccc}
\hline & $\begin{array}{c}\text { Maxim of } \\
\text { quantity }\end{array}$ & $\begin{array}{c}\text { Maxim } \\
\text { of } \\
\text { quality }\end{array}$ & $\begin{array}{c}\text { Maxim of } \\
\text { relevance }\end{array}$ & $\begin{array}{c}\text { Maxim } \\
\text { of } \\
\text { manner }\end{array}$ & Total \\
& 42 & 24 & 17 & 5 & 88 \\
$\%$ & $36.96 \%$ & $21.12 \%$ & $14.96 \%$ & $4.4 \%$ & $100 \%$ \\
\hline
\end{tabular}

From the table above, it can be seen that the majority of maxim violation that happened during the class was the maxim of quantity ( 42 times or $36.96 \%$ ). The violation of maxim of quantity is when a person gives too much information, more than what is being asked. Generally, this is common for a teacher and lecturer to give more information than what is asked by his/her students in order to make the explanation clearer and students' can understand the point as a whole. as Ur (2000) suggests, teacher talk is an important segment in the process of teaching and learning as it can develop students' language acquisition as well as idea or concept expansion. The sum and sort of teacher talk is even viewed as a definitive factor of progress in classroom instructing.

The excerpt from the data is as shown below:

\section{Excerpt 1}

SM : not so many, Sir?

$T \quad$ : no, take your communication book guys! Done? Give it to me I will sign. Rise up your hand I will come to you ok?

From the excerpt above, we can see that the student SM only asked 'no so many teacher?' where the teacher should only answer 'yes' or 'no'. However, the teacher gave more information, in this case, a command. He asked the student to prepare another book to be graded.

Later, the second maxim violation that happened during the class is the maxim of quality which happened for 24 times or $21.12 \%$. A person is considered to perform the violation towards the maxim of quality is when she/he inserts an untruthful answer-or giving information that she/he is not sure of. However, in teacher talks, this type of maxim violation generally happened when the lecturer wanted to make some jokes with his/her students so that the learning atmosphere can be more comfortable and not strenuous. The datum can be seen in the excerpt below.

\section{EXCERPT 2}

SS: nomor 5 "Never try smoking" jawabannya.

T:iya betul. "Never try smoking". Jadi, buat cowok ingat ya. Buat yang cewek nggak usah dekat dekat ya.

From the excerpt above it can be seen that the lecturer was saying 'Jadi, buat cowok ingat ya. Buat yang cewek nggak usah dekat dekat ya' that he was not really sure of. In addition, there is no empirical proof showing that all boys in that room smoke, and all girls will not approach a boy who smokes. Then, this is considered as the violation of maxim of quantity.

Next, it is the violation of maxim of relevance that happened for 17 times or $14.96 \%$. The violation on the maxim of relevance happens when a person give an irrelevant answer toward a question being asked. In this case, the lecturer was trying to control various different questions at a time. So that, it is very unlikely to answer only one question at one time alone. sometimes, the lecturer also answered questions, gave directions, or called on a students at the same time. The datum is as shown in the excerpt below.

\section{EXCERPT 3}




\section{SF2 : Sir, this is correct?}

$T \quad$ : next I will check all of them. Don't look at your friends' work! Ok everybody next, now gather your all books please! You at the back, please stop it. Ok everybody open your module please on page 96.

On the excerpt above, it is clearly shown that the students asked whether her answer was correct or not, then the lecturer answered with a certainly irrelevant answer that he would check all of them (the answers). In this case, the violation on the maxim of relevance occured. However, taking the sight from the situational context, it can be seen that he lecturer was quite busy at that time because some other student was cheating from a friend's work, while another student was talking at the back. From this situation, it is understood that a one-to-one conversational accomplishment can be hard to achieve.

Last, it is the violation of maxim of manner,which happened only 5 times or $4.4 . \%$. A person is said to violate the maxim of manner when she/he says something unclear or tries to say it indirectly. This rarely happened in the class during the teaching and learning process because when making explanation, the lecturer wanted his explanation to be clear and concise. However, once in a while he also performed the violation of maxim of manner in attempt to sound more complex and intricated. The datum is as shown in the following.

\section{EXCERPT 4}

S3:Ini besok dikirim, diketik ulang, Pak?

\section{T: Don't worry!Jangan susah-susah kalau disuruh ketik ulang. Semakin kalian nulis semakin bisa kalian belajar. Kok takut banget ketik ulang? Sedikit-sedikit lama-lama menjadi bukit.}

From the excerpt above we can see that when the lecturer answered the students with a long and complicated answer, he violated the maxim of manner. His answer substantively confused the student because the answer needed was only 'yes' or 'no'. However, the lecturer prolonged it and even enclosed a proverb at the end. Although, indeed, his answer becomes more meaningful, it is evidently violating the Gricean maxim of manner.

\section{Conclusion}

From the result, it can be seen that the majority of Gricean Maxim violation occurred in the type of maxim of quantity $(36.96 \%)$. Then it is followed by maxim of quality $(21.12 \%)$ and maxim of relation $(14.96 \%)$. And the least violation occurred is the maxim of manner (4.4.\%).

\section{References}

[1]. P. Ajayi. Primary sources of data and secondary sources of data. Makurdi: Benue State University Press. 2017. Accessed from: https://bit.ly/3797Fmk

[2]. M. Hennink, I. Hutter, \& A. Bailey. Qualitaitive research methods. London: Sage Publications. 2011.

[3]. F. Lupke. "Research method in language documentation". In Language Documentation and Description, P. K. Austin, Ed, London: SOAS, 2010, pp. 55-104.

[4]. N.P. Himmelmann. "Language documentation: What is it and what is it good for?" In Essentials of Language Documentation, J. Gippert, N. P. Himmelmann, and U. Mossel, Eds, Berlin: Mouton de Gruyter, 2006, pp. 1-30.

[5]. L.R. Horn, \& G. Ward. The Handbook of Pragmatics. Victoria: Blackwell Publishing. 2006.

[6]. T. Kurdghelashvili. "Speech Acts and Politeness Strategies in an EFL Classroom in Georgia", International Journal of Social, Behavioral, Educational, Economic, Business and Industrial Engineering, vol 9, pp. 306-309, 2015. 
[7]. M. Margana. "Pragmatic Knowledge for Second Language Learners", Journal of English and Education Universitas Islam Indonesia, vol.5, pp. 54-73, 2011.

[8]. J. L. Mey. Pragmatics: An Introduction. London: Blackwell Publishing. 2001.

[9]. L. J. Moleong. Metode penelitian kualitatif [Qualitative research methods]. Yogyakarta: PT. Remaja Rosdakarya. 2013.

[10]. H. P. Grice. 1975 "Logic and Conversation”. In Syntax and Semantics 3: Speech Act, P. Cole and J.L. Morgan, Eds, pp.41-58, Boston: Academic Press. 1975.

[11]. J. L. Mey. Concise Encyclopedia of Pragmatics. Elsevier. 2009.

[12]. S. Purwaningsih. The pragmatics analysis of the cooperative principle in a comedy movie entitled "Meet The Parents". Salatiga: IAIN Salatiga, 2015.

[13]. K. Porayska-Pomsta, C. Mellish, and H. Pain. Pragmatic Analysis of Teachers' Language. Towards an Empirically Based Approach. AAAI Technical Report FS-00-01. 2000. Retrieved from https://www.aaai.org/Papers/Symposia/Fall/2000/FS-00-01/FS00-01019.pdf.

[14]. Searle, J. R. Expression and Meaning: Studies in the Theory of Speech Acts. Cambridge: Cambridge University Press. 2005.

[15]. P. Ur. A Course in Language Teaching Practice and Theory. Beijing: Foreign Language Teaching and Research Press. 2000.

[16]. R. Wardhaugh. An Introduction to Sociolinguistics. Oxford: Blackwell. 2006.

[17]. G. Yule. The Study of Language. Cambridge: Cambridge University Press. 2005.

[18]. G. Yule. Pragmatics. Oxford: Oxford University Press. 2006.

[19]. A. Zulfa. The flouting of grice's conversational maxims By the main character in the Dictator movie. Malang: Brawijaya University, 2013.

[20]. J. Thomas, J. Meaning in Interaction: An Introduction to Pragmatics. London: Longman. 1995.

[21].G.A. Bowen. "Document Analysis as a Qualitative Research Method", Qualitative Research Journal, vol. 9, pp. 27-40, 2009.

[22].M.B. Miles, A. M. Huberman, and J. Saldana. Qualitative Data Analysis. LA: SAGE publication 2014. 